\title{
Impact of Information Technology Skills on Old and New Generation Secretarial Teachers in Nigeria Colleges of Education to Utilize Internet for Classroom Delivery
}

By

${ }^{*}{ }^{1}$ Adeshina, Tunde Joel; ${ }^{2}$ Udoh, Abasido; ${ }^{3}$ Ndomi, Benjamin; and ${ }^{2}$ Aliyu, Muhibeedeen.

\begin{abstract}
This study established the difference between the old generation and new generation secretarial Teachers in Nigerian Colleges of Education and their ability to utilize Information Technology skills to access information from the internet for classroom delivery. 250 Secretarial Teachers drawn from 58 Accredited Nigerian Colleges of Education responded to the questionnaire that was divided into 4 parts. The questionnaire was used to obtained information on the respondents' Bio-data and computer use background, Teacher Information Technology Skill Acquisition Competence (TITSC), Teacher Information Technology Skills Usage (TITSU), Teacher Information Technology Internet Knowledge (TITIK), and The extent of usage of Internet information to teach the Secretarial courses. Data were analyzed using descriptive statistics and Student t-test at 0.05 level of significance. Results showed that there was no significant difference between the Old and New generation Secretarial Teachers in the utilization of their IT skills to access information from the Internet for classroom delivery. The result also revealed that there was a gap between the old and the new generation Secretarial teachers. The new were more proficient in the use of IT than the old because they were products of the revised Nigerian Certificate of Education (2002) which was enriched with Information Technology learning materials. Although there were some basic IT skills needed that were lacking in both the old and new generation Secretarial Teachers, hence were handicapped in their ability to download and upload quality information and teach students how to do that. Owing to the lack of these IT skills therefore, the teachers were not capable in accessing Internet by using some Information Technology facilities to get vital information for effective classroom delivery. it was therefore recommended that, Secretarial Teachers in Colleges of Education should avail themselves with the opportunity of staff development programme of their respective institutions or through self sponsorship to learn and acquire those IT skills they are lacking, because the more the Information Technology skills they possess, the greater their ability to use Internet for effective classroom delivery.
\end{abstract}

Keywords: Information Technology (IT) skills, Internet utilization, Lecture Delivery

1. Department Of Business Education, Federal College of Education, Zaria, Nigeria

2. Department of Vocational and Technical Education, Ahmadu Bello University, Zaria, Nigeria

3. Department of Vocational Education, Modibo Adama University of Technology, Yola

*Corresponding Author 


\section{Introduction}

Secretarial Education was designed as a programme in Business Education for Students to opt for by the National Commission for Colleges of Education (NCCE) in 1985 and placed emphasis on Typewriting, Shorthand and Office related disciplines. With the introduction of Information Technology in 2001, Secretarial Education was repositioned. The 2002 review of the Nigerian Certificate of Education (NCE) minimum standards incorporated some major elements of Information Technology into the teaching of secretarial education. Such courses included Computer Appreciation, Information Technology, and Word Processing. The course descriptions include the acquisition of skills on Computer hardware and software, Computer Techniques, Programming Languages, Information Technology Concepts, Word Processing, Electronic Data Application Systems and Electronic Communication systems (NCCE, 2002).

With this document put in place for implementation in the Nigerian Colleges of Education, acquisition of IT competencies and ability to utilize such competencies became imperative. Therefore, if secretarial teachers are to graduate students that would be relevant in the secretarial world of work, they must possess and utilize these skills effectively. Although provisions have been made for teachers to acquire Information Technology skills, so as to qualify to teach in the entire Business Education Programme, Computer Literacy is a requirement. However, it is not clear whether all the secretarial teachers have the Information Technology skills, hence the need to assess the level of their IT skills and to see how much of it they have been able to use it to access information from the Internet for effective teaching delivery and production of IT compliant products.

It is important to note that there has to be a relationship between the skill possessions by these Secretarial Teachers and ability to use for teaching delivery, before there can be a drive towards having an improved teaching pedagogy. The use of IT to teach certainly has an advantage over the traditional method of depending on outdated books to teach. The more the IT skills possessed by Secretarial Teachers, the more the ability to seek for more detailed up-to-date and relevant information that will promote effective teaching delivery and vice versa. The most critical factor in the successful integration of Information Technology into education is the extent to which teacher educators are able to prepare teachers with the required knowledge and skills to utilize Information Technology effectively (Information and Communication Technology in Education, 2004). Oliver (2002) in Oluwalola (2006) identified the needs for student teachers to experience models of Information Technology use in their 
own learning before they can go ahead to implement same in their later profession.

Teacher education institutions may either assume a leadership role in the transformation of education or be left behind in the swirl of rapid technological change (UNESCO, 2002). This is because the teacher is an agent of change, therefore cannot operate from the background but take the leading role in imparting this needed skill. The need for the development of Information and Communication Technology is a global resolution and has been a subject of great significance to all mankind (Idih and Njoka, 2008). These technologies have become central to contemporary societies. Whether one is talking on phone, sending an e-mail, going to the bank, using a library, listening to sports coverage on the radio, watching the news on television working in an office or in field, going to the doctor, driving a car or catching a plane, one is using Information Technology.

Adeshina (2006) posited that secretarial course contents are related to Information Technology. The job description of secretaries along which they are trained includes: receiving, processing, storing, retrieving and transmitting information. With the use of IT the jobs of the secretary in the office are being greatly enhanced as the jobs are carried out with ease, accurately and in real time. The secretarial teacher, therefore, cannot afford to be IT illiterate if he must produce secretaries or secretarial educators. To support this view, the reviewed 2002 NCCE curriculum took into cognizance the new trend in modern offices. The curriculum in use before this 2002 review used manual machines, and most of the old generation secretarial teachers had their training in secretarial education without the use of modern IT equipment. Njoku (2000) therefore, suggests the need to retrain them.

\section{Objective Of The Study}

The objective of this study was to establish the difference between the old generation and new generation secretarial teachers in using Information Technology skills to access information from the internet for classroom delivery.

\subsection{Research Question}

What is the difference between the old and new generation secretarial teachers in using Information Technology skills to access information from the internet for classroom delivery? 


\subsection{Research Hypothesis}

The null hypothesis was tested at 0.05 level of significance:

There is no significant difference between old and new generation secretarial teachers in using Information Technology skills to access information from the internet for classroom delivery.

\section{Methods}

The study used survey design with 250 Secretarial (Business Education) Teachers drawn from 58 accredited Nigerian Colleges of Education. No sampling was done because of the small size of the target population. However, out of the 250 Secretarial Teachers, only 225 Secretarial Teachers responded to the questionnaire that was divided into 4 parts. Questionnaire was used to obtained information on the respondents' Bio-data and computer use background, Teacher Information Technology Skill Acquisition Competence (TITSC), Teacher Information Technology Skills Usage (TITSU), Teacher Information Technology Internet Knowledge (TITIK), and The extent of usage of Internet information to teach the Secretarial courses. The items were scored using 4 point scale as follows: Adequately Skilled $=4$, Skilled 3, Fairly Skilled $=2$, Not Skilled =1; Very Well $=4$, Well $=3$, Fairly Well $=2$, Not at all $=1$, Very Knowledgeable $=4$, Knowledgeable $=3$, Fairly Knowledgeable $=2$, Not Knowledgeable $=1$; Very Often $=4$, Often $=3$, Occasionally $=2$, Never $=1$; Very Much $=4$, Much $=3$, Little $=2$, Not at all $=1$. The STITB Instrument was validated through pilot study in Kaduna and Zaria Polytechnics using graduates of Secretarial Business Education and whose colleges also run similar secretarial programmes as in the Nigerian Colleges of Education. The reliability coefficient of 0.90 was obtained. The research instruments were administered by the researcher on 250 Secretarial Teachers with the assistance of 12 field assistants, however, only 225 participants returned the instrument duly completed.

\subsection{Results}

Tables 1 through 10 showed the results. Data were analyzed using simple percentage and student t-test. 


\section{Analyses of Bio Data:}

Table 1 Percentage of Respondents by Generation of Secretarial Teachers

\begin{tabular}{|l|r|l|}
\hline Old and New Generation & Frequency & Percent \\
Secretarial Teachers & & 64.9 \\
\hline Before 2002 (Old Generation) & 146 & 20.0 \\
After 2002 (New Generation) & 45 & 15.1 \\
No date indicated & 34 & 100.0 \\
\hline Total & 225 & \\
\hline
\end{tabular}

Source: Field Survey, 2011

Table 2 Percentage of Respondents by Age

\begin{tabular}{|l|c|c|}
\hline Age (in Years) & Frequency & Percent \\
\hline Less than 25 & 1 & 0.4 \\
$25-29$ & 8 & 3.6 \\
$30-34$ & 24 & 10.7 \\
$35-39$ & 34 & 15.0 \\
$40-44$ & 62 & 27.6 \\
$45-49$ & 53 & 23.6 \\
$50-54$ & 31 & 13.8 \\
$55-59$ & 9 & 4.0 \\
Above 59 & 2 & 0.9 \\
No Age Indicated & 1 & 0.4 \\
\hline Total & 225 & 100.0 \\
\hline
\end{tabular}

Source: Field Survey, 2011

Table 3 Percentage of Respondents by Educational Qualifications

\begin{tabular}{|l|c|c|}
\hline Qualification & Frequency & Percent \\
\hline Bachelor Degree & 57 & 25.3 \\
Masters Degree & 145 & 64.5 \\
Doctorate Degree & 9 & 4.0 \\
Others & 14 & 6.2 \\
\hline Total & & \\
\hline
\end{tabular}

Source: Field Survey, 2011

Table 4 Percentage of Respondents by Rank

\begin{tabular}{|l|c|c|}
\hline Rank & Frequency & Percent \\
\hline Chief Lecturer & 15 & 6.7 \\
Principal Lecturer & 23 & 10.2 \\
Senior Lecturer & 54 & 24.0 \\
Lecturer 1 & 26 & 11.5 \\
Lecturer 2 & 31 & 13.8 \\
Lecturer 3 & 33 & 14.7 \\
Assistant Lecturer & 38 & 16.9 \\
No Rank indicated & 5 & 2.2 \\
\hline Total & 225 & 100.0 \\
\hline
\end{tabular}

Source: Field Survey, 2011 
Table 5 Percentage of Respondents by Years of Teaching Experience

\begin{tabular}{|l|c|c|}
\hline $\begin{array}{l}\text { Teaching Experience } \\
\text { (in Years) }\end{array}$ & Frequency & Percent \\
\hline $1-3$ & 28 & 12.5 \\
$4-6$ & 41 & 18.2 \\
$7-10$ & 45 & 20.0 \\
$11-15$ & 31 & 13.8 \\
Above 15 & 79 & 35.1 \\
Not indicated & 1 & 0.4 \\
\hline Total & 225 & 100.0 \\
\hline
\end{tabular}

Source: Field Survey, 2011

Table 6 Percentage of Respondents by their Previous Computer Training

\begin{tabular}{|l|c|c|}
\hline Formal computer training & Frequency & Percent \\
\hline Had previous training & 189 & 84.0 \\
No previous training & 33 & 14.7 \\
No response & 3 & 1.3 \\
\hline Total & 225 & 100.0 \\
\hline
\end{tabular}

Source: Field Survey, 2011

Table 7 Percentage of Respondents by Computer Accessibility

\begin{tabular}{|l|c|c|}
\hline Computer accessibility & Frequency & Percent \\
\hline Not accessible & 7 & 3.1 \\
Occasionally accessible & 39 & 17.4 \\
Restricted access & 3 & 1.3 \\
Freely accessible & 173 & 76.9 \\
No response & 3 & 1.3 \\
\hline Total & 225 & 100.0 \\
\hline
\end{tabular}

Source: Field Survey, 2011

Table 8: Mean Ratings of the Responses of the Old and New Generation Secretarial Teachers in their IT Skill Competence.

\begin{tabular}{|l|l|l|l|l|}
\hline Generation & N & $\bar{x}$ & SD & Remark \\
\hline Old & 146 & 2.66 & 0.54 & Skilled \\
New & 45 & 2.69 & 0.68 & Skilled \\
No response & 34 & & & \\
\hline
\end{tabular}

Source: Field Survey, 2011

Table 9: Mean Ratings of Responses of the Old and New Generation Secretarial Teachers in the use of IT Skills to Access Information from the Internet.

\begin{tabular}{|l|l|l|l|l|}
\hline Generation & N & $\bar{x}$ & SD & Remark \\
\hline Old & 146 & 2.59 & 0.75 & Well used \\
New & 45 & 2.71 & 0.80 & Well used \\
No response & 34 & & & \\
\hline
\end{tabular}

Source: Field Survey, 2011 
Table 10: $\mathrm{t}$-Test of Mean Responses by Old and New Generation Secretarial Teachers on IT Skills Utilization to Access Information from the Internet for classroom delivery.

\begin{tabular}{|l|l|l|l|l|l|l|}
\hline Variables & $\mathrm{N}$ & $\overline{\mathrm{x}}$ & $\mathrm{SD}$ & $\mathrm{DF}$ & $\mathrm{t}$-value & Decision \\
\hline Old Generation & 146 & 2.59 & 0.75 & & & \\
\cline { 1 - 4 } New Generation & 45 & 2.71 & 0.80 & 189 & 0.896 & NS \\
\hline
\end{tabular}

Table 1 showed that 146 Secretarial Teachers representing 64.9\% were taught with the Pre 2002 National Commission for Colleges of Education (NCCE) minimum standard that was not ICT inclusive, which may be termed the old generation Secretarial Teachers. While only $45(20.0 \%)$ were of the new breed teachers (New generation Secretarial Teachers) that were trained with the ICT enriched NCCE Minimum Standards. 34 (15.1\%) respondents did not indicate whether they were old or new generation Secretarial Teachers.

Table 2 showed that in the next nine (9) years from here when Nigeria would have become one of the 20 developed economies, only 11 lecturers out of the current respondents would have been out of the system by reason of retirement from their respective places of employment. These 11 lecturers fall within the clusters of ages 55-59 (9) (4.0\%) and 59 and above (2) (0.9\%). The remaining 212 lecturers that would carry on with Secretarial Education Teacher service delivery into the 20:20:20 vision and beyond would still impact positively, with the ICT skills they possess, on the students currently in the programme and potential students.

Table 3 showed that the Colleges of Education in Nigeria were equipped with qualified post graduate teachers to teach the secretarial Education. This will go a long way to offset any deficiency in curriculum, in textbooks and in equipment.

Table 4 revealed that the Colleges of Education in Nigeria are equipped with qualified teachers that are also well advanced in their teaching experiences as could be seen in their respective ranks. The Colleges of Education were not bottom heavy as there are $52.4 \%$ Senior Academics that can mentor the other $47.6 \%$ for a positive teaching learning processes.

Table 5 showed that the Colleges of Education in Nigeria are not only equipped with qualified Teachers who had rose to become senior academics, but their years of teaching experience attested for them. These lecturers that have at least four years of teaching experience sum up to $87.1 \%$, who by regulation had their appointments confirmed.

Table 6 showed something very impressive on the part of these teachers. The result indicated that many of them that had no computer literacy made personal effort to acquire the skills. This effort supported or agreed with the recommendations of Ugwuanyi and Eze (2009), that, teachers are expected to make personal efforts to have their own personal computers and engage private 
teachers where possible. This will make them become useful in the IT compliant classroom, as they will be able to teach effectively, giving quality information obtained from the internet.

Table 7 revealed the respondents' computer accessibility. The result was commendable as they had access. It is important to note that there were some Colleges of Education that collaborated with computer sales depot and Information Technology service providers. This partly explained for the improved accessibility of teachers to computer. The learning of Information Technology skills will only be meaningful to the extent that equipment for teaching was available and functional.

Table 8 indicated that the Old and New Generation secretarial teachers were IT skilled; however, the mean rating of the New Generation Secretarial Teachers (2.69) was higher than that of the Old Generation Secretarial Teachers (2.66) in their IT skill competence. The difference was 0.03 in the mean rating. The New generation secretarial teachers, as shown here, are more IT competent than the Old generation secretarial teachers. There is also the possibility that the new generation teachers will do better than the old generation teachers in their ability to access the Internet for classroom delivery.

The result in Table 9 showed that the old and new generation secretarial teachers used well their IT skills; however, there was a higher mean rating for the new generation secretarial teachers (2.71) than the old generation secretarial teachers (2.59) on their usage of Information Technology (IT) skills to access information from the Internet. There was a difference of 0.12 . The standard deviations of the generations were not too far apart showing that they were close in their opinions. It was discovered that the New Generation Secretarial Teachers' ability to use the Internet more than the Old Generation was consequent upon the effect that the 2002 Minimum Standards enriched with IT experiences have on them. Except something is done to bridge this gap, the new generation will continue to have this comparative advantage over the old generation teachers in effective lesson delivery using IT.

Table 10 showed that the t-critical (1.96) was greater than t-cal (0.896). The difference between the means of the two groups was not different. The difference observed was not significant. There was therefore, no significant difference between the old and new generation secretarial teachers in the utilization of their IT skills to access information from the Internet for classroom delivery; hence the Null Hypothesis is hereby retained. This was also because the result was positive. The results suggested that the IT skills that Old and New generation secretarial teachers possessed do have an effect on their ability to access information from the Internet for classroom delivery. Specifically, the results suggested that when more IT skills were possessed by the Secretarial 
Teachers, they had increased ability to access information from the Internet for classroom delivery.

\section{Findings}

The summary of the major finding was that the old and new generation secretarial teachers showed a well utilized Information Technology skill to access information from the Internet except in these areas: ability to operate data base, ability to extract relevant information using integrated software packages, ability to extract information using electronic mails and application software, ability to use voice recognition system and ability to operate other different technologies and appreciate their benefits. These inabilities were discovered to be more associated with the old generation secretarial teachers.

\subsection{Discussion}

The findings of this research concerning the comparative advantage the New generation teachers have over the Old generation teachers obtains support from what Nolan, Harden and Malsbury (1976) as cited by Oladebo (1987) said that no curriculum however well written they may be, however costly it may be, will compensate for a poor business teacher. On the other hand, good business teachers will more than offset deficiencies in curriculum, in textbooks and in equipment. This assertion attested to the important role the secretarial (business) education teacher plays in the development of a viable secretarial (Business) education programme. With professionally sound and motivated secretarial (Business) education teachers, many deficiencies in the curriculum and the instructional facilities could be corrected.

Result of the study showed that the old generation secretarial teachers had to go for a retraining to acquire some level of IT skills to be able to teach with the reviewed minimum standard that came into force in 2002 that was enriched with IT components and subject matter. Those who have to go for retraining certainly were not in touch with IT learning experiences, all about the IT policy which was signed into law in 2001, led to the review of the minimum standard that now had IT incorporated into it. In order to perfect on these skills, and avoid becoming obsolete, it would be expedient for the stakeholders in the Education sector to continue to give a continuous workshops, seminars and conferences to train the trainers. This is in line with Chibuike and Igboke (2009) who reported that, those that are ignorant of modern IT should devise a means to get acquainted and familiarize with them to avoid being laid off. While supporting the above statement, Ugwuanyi and Eze (2009) recommended a retraining so that these teachers would be able to handle secretarial courses well. Every teacher who submits to a retraining is good gesture towards promoting 
efficiency in teaching and learning. It is important to note that, whatever was the reason for not using a computer by any teacher in this IT compliant educational sector is no excuse, for such teachers will soon become obsolete in the teaching profession.

The result also showed that the teachers who were not computer literate made personal effort to acquire the skills. This effort supported or agreed with the recommendations of Ugwuanyi and Eze (2009), that, teachers should make personal efforts to have their own personal computers and engage private teachers where possible. If any teacher in the field of secretarial education is to remain relevant, in this age of technology, the lack of competencies in IT, and the equipment must be addressed. This observation lent credence to what Azuka (2003) said that, the learning of business skills (of which secretarial education is inclusive) can only be meaningful to the extent that equipment for teaching are available and functional.

\section{Conclusion}

In view of the findings of the study, the comparative advantage the new generation Secretarial teachers have over the old generation Secretarial Teachers means additional cost on the part of the old generation Teachers, employers and other stakeholders. To retrain or train will involve spending money. In view of the findings, those teachers that were not exposed to the 2002 IT enriched curriculum (termed the old generation Teachers), will not be relevant in the teaching industry. In this case, these teachers would soon become obsolete and will affect the quality of the materials used for teaching and learning of Secretarial Education in the Colleges of Education in Nigeria.

\section{Recommendations}

However, in view of the findings and discussions, it is hereby recommended that, Secretarial Education Teachers in the Colleges of Education in Nigeria should avail themselves with the opportunity of staff development programme of their respective institutions in order to get appropriate and adequate training in IT: through in-service training, part time programmes, and attendance to conferences, workshops and seminars. They could also update and improve themselves through the process of self-sponsorship training in private computer/business centers as well as in house (departmentally arranged) training scheme. The mentoring approach could be employed here, where the older Teaching staff that is Information Technology skilled can develop training sessions at free period or at weekends to build the capacity of others who may be deficient in IT usage. 


\section{References}

Adeshina, T. J. (2006) ICT Implication for Vocational Business Education in Nigeria. Journal of Office Management and Technology. Auchi Polytechnic, Edo state 1 (1) 259-264

Azuka, E. B. (2003): "Availability and Functionality of Business Education Equipment and Facilities in Selected Polytechnics in Nigeria." Business Education Journal. 4 (1) 107-114

Chibuike V .C. and Igboke, S. A. (2009) Adequacy of Information and Communication Technology content taught to Business Education students in Nigeria Tertiary Institutions. Business Education Journal 3 (1) 36-45.

Federal Republic of Nigeria (2002) Minimum Standard for NCE Vocational Teacher.

Curriculum and course specification, NCCE Press, Abuja

Federal Republic of Nigeria (2004) National Policy on education. NERDC Press, Yaba-Lagos

Idih, E. I. N. and Njoka, J. U. (2008) ICT Based Curriculum for Restructuring the delivery of Business Education in Nigeria. Association of Business Educators of Nigeria- Book of Readings 1 (8) 229-237

National Commission for Colleges of Education, Abuja (2002) Minimum Standards for Nigerian Certificate in Education: Vocational and Technical Education. $3^{\text {rd }}$ Edition

Njoku, C. U. (2000) Teaching Secretarial Administration Subjects in a Modern Technological Age: The journey so far. Business Education Journal, 3 (3) 244-252

Oladebo, S.A. (1987). The challenges of the "New National Policy on Education" to business educators. Business Education Journal 2 (1) 32-39.

Oluwalola, F. K. (2006) Effects of Information and Communication Technology on Secretarial Workers: Journal of Office Management and Technology, Auchi Polytechnic, Edo State, Nigeria 1 (1) 94-101

Ugwuanyi, M. O. and Eze, M. E. (2009): Strategies for Effective Implementation of ICT Driven Curriculum for Secretarial Studies Programme for Secretarial Studies Programme in Nigerian Polytechnics. Business Education Journal 7 (1) 62-69

UNESCO (2002) Technical and Vocational Education and Training for the $21^{\text {st }}$ Century website: http://www.unesco.org.edu Retrieved on 20 $0^{\text {th }}$ November, 2010 
